\title{
MENIMBUN BARANG (IHTIKAR) PERSPEKTIF HADIS (SUATU KAJIAN TEMATIK)
}

\author{
A. Intan Cahyani \\ Universitas Islam Negeri Alauddin Makassar
}

\begin{abstract}
Hadith research on ihtikar and especially on the hadith relating to the forbidden ihtikar which is the object of research in this paper is the quality of authentic Hadith, both viewed from the sanad and its mature quality. Therefore, this hadith can be used as a legal basis in establishing Islamic law. The Hadith states the prohibition on doing ihtikar with the phrase "la yahtakiru illa khathi'un", regarding the hadith jumhur Ulama agreed on the prohibition of ihtikar. However, they differed on the method used to determine the prohibition of ihtikar. Because ihtikar's actions can cause instability in society, ihtikar's perpetrators are very appropriate if given severe criminal sanctions and in accordance with their actions.
\end{abstract}

Keywords: Ihtikar, Haram, Law, Jumhur Ulama.

\begin{abstract}
Abstrak
Penelitian hadis tentang ihtikar dan terkhusus lagi pada hadis yang berkaitan dengan keharaman ihtikar yang menjadi obyek penelitian dalam makalah ini adalah kualitas Hadis shahih, baik dilihat dari sanad maupun kualitas matangnya. Oleh karena itu, hadis tersebut dapat dijadikan landasan hukum dalam penetapan hukum Islam. Hadis menyatakan larangan melakukan perbuatan ihtikar dengan ungkapan "la yahtakiru illa khathi'un", mengenai hadis tersebut jumhur Ulama sepakat mengenai keharaman ihtikar. Namun demikian, mereka berbeda pendapat mengenai cara yang digunakan dalam menetapkan keharaman ihtikar. Oleh karena tindakan ihtikar dapat menimbulkan instabilitas dalam masyarakat, maka pelaku ihtikar sangat tepat bila diberi sanksi pidana yang berat dan sesuai dengan perbuatannya.
\end{abstract}

Kata Kunci: Ihtikar, Haram, Hukum, Jumhur Ulama.

\section{PENDAHULUAN}

Sebagai agama yang telah disempurnakan, Islam yang dibawakan oleh Nabi Muhammad saw. memberikan pedoman hidup yang menyeluruh, meliputi bidang aqidah, ibadah, akhlak dan mu'amala yang keseluruhannya itu telah dietapkan oleh Allah swt. dalam al-qur'an. ${ }^{1}$ Adapun bentuk pelaksanaannya, Rasulullah

\footnotetext{
${ }^{1}$ Sayyid Muhammad Rizvi, Kecendrungan Rasionalisasi dalam Hukum Syari'at, dalam Jurnal al-Huda, Volume 2 Nomor 5 2002, h. 57.
}

27 El-Iqtishady | Volume 2 Nomor 1 Tahun 2020 
kemudian menjabarkannya melalui berbagai hadis untuk dijadikan pedoman bagi umat manusia dalam kehidupan sehari-hari.

Terkhusus untuk masalah mu'amalah diakui secara sosiologis, manusia dalam hidupnya membutuhkan berbagai macam kebutuhan. Kebutuhan manusia secara umum meliputi: al-Ma'kulat wa al-masyrubat (makan dan minum), al-malbusat (pakaian), al,markubat (kendaraan), al-maskunat (tempat tinggal) dan almankuhat (perkawinan). ${ }^{2}$ Untuk memenuhi kebutuhan manusia tersebut, manusia diwajibkan berusaha dan berikhtiar untuk kemudian menyerahkan hasilnya kepada keputusan Allah swt.

Salah satu bentuk mu'amalat yang sering dijumpai sehari-hari adalah jual-beli, terlebih karena jual-beli merupakan bentuk mu'amalat yang paling lazim dilakukan manusia untuk memenuhi kebutuhan hidupnya. Namun, seiring dengan perkembangan zaman, manusia seringkali lupa diri dan terjerumus dalam kehidupan yang hedonistis dan individual, dimana manusia tidak lagi peduli terhadap nilai-nilai Islam yang merupakan prinsip dalam jual-beli. Salah-satu bentuk penyimpangan yang sering ditemui di masyarakat yaitu adanya upaya penimbunan barang (Ihtikar) yang merupakan hajat hidup orang banyak disimpan dalam waktu lama untuk kemudian menaikkan harganya pada waktu tertentu. Misalnya sembako, bahan bakar dan sebagainya, sehingga mengganggu sistem ekonomi dan dapat menimbulkan instabilitas dalam negeri.

Kenyataan tersebut sepertinya sudah menjadi kegiatan rutin para oknum yang tidak bertanggung-jawab. Terlebih lagi setiap menjelang perayaan Hari-Hari Besar Nasional, seperti Ramadhan hingga Hari Raya 'Iedul Fitri, Natal dan Tahun Baru dan sebagainya. Hal itu jelas menjadikan masyarakat yang sudah susah semakin menderita dan di satu pihak orang-orang tertentu yang diuntungkan. Jika demikian bagaimana pandangan hadis terhadap ihtikar tersebut.

Berdasarkan latar belakang tersebut di atas, maka yang menjadi permasalahan dari tulisan ini adalah Bagaimana kualitas sanad dan matan hadis Ihtikar. Bagaimana bentuk pengharaman hadis mengenai ihtikar.

\section{METODE PENELITIAN}

Penelitian ini dilakukan berdasarkan studi pustaka dengan berbagai referensi jurnal dan buku serta beberapa artikel terbaik dan terupdate. Penelitian Pustaka (library research) yaitu Penelitian dilaksanakan dengan mengumpulkan data dan landasan teoritis dengan mempelajari buku, karya ilmiah, hasil penelitian terdahulu, jurnal-jurnal terkait, artikel-artikel yang terkait serta sumber-sumber

${ }^{2}$ Ahmad Azhar Basyir, Garis Besar Sistem Ekonomi Islam, (Yogyakarta: BPFE, 1987). h. 2.

28 
yang terkait dengan penelitian sesuai dengan penelitian yang diteliti. Setelah semua data telah diperoleh berhasil dikumpulkan selama proses penelitian baik data primer dan data sekunder dianalisis secara kualitatif kemudian disajikan secara deskriptif yaitu menjelaskan, menguraikan, menggambarakan permasalahan yang berkaitan dengan menimbun barang (ihtikar) dalam perspektif hadis yang merupakan suatu kajian tematik.

\section{PEMBAHASAN}

\section{A. Kritik Hadis Mengenai Keharaman Ihtikar}

Informasi hadis mengenai keharaman menimbun barang terdapat sebanyak 12 hadis, yang tersebar dalam berbagai kitab hadis. Dalam kitab shahih Muslim 2 hadis, Sunan Abu Daud 1 hadis, Sunan at-Tirmidzy 1 hadis, Sunan Ibn Majah 1 hadis, Musnad Ahmad bin Hambal 5 hadis, Muwaththa' Malik 1 hadis, dan Sunan ad-Darimy 1 hadis.

Adapun hadis tentang hukum ihtikar yang akan dijadikan sasaran penelitian dalam penulisan hadis tematik ini adalah dua buah hadis yang terdapat dalam kitab hadis shahih Muslim dan satu hadis dalam kitab Sunan Ibn Majah, sebagai berikut:

1. Shahih Muslim.

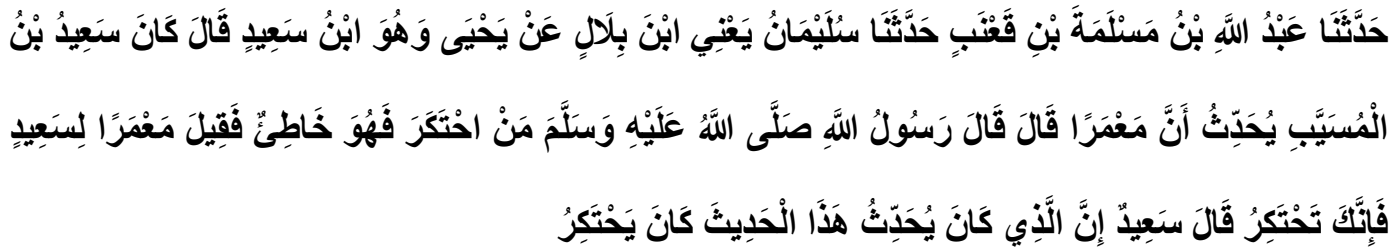

Terjemahannya:

'Abdullah bin Musallama bin qa'nabin menyampaikan kepada kami,bahwa sulaiman (ibn bilal) telah menyampaikan dari Yahya (anaknya said) berkata bahwa pernah suatu saat Said bin al-Musayyab menyampaikan bahwa Ma'mara berkata, bersabda Rasulullah saw.: "Barang siapa yang telah menimbun barang maka ia adalah orang yang dilaknat", maka ditanyalah kepada Said bahwa sesunggunya engkau telah menimbun barang, dijawab Said bahwa hanya Ma'maralah yang telah menyampaikan berita ini kalau pernah ada orang yang menimbun barang.(H.R.Muslim)

2. Shahih Muslim. 


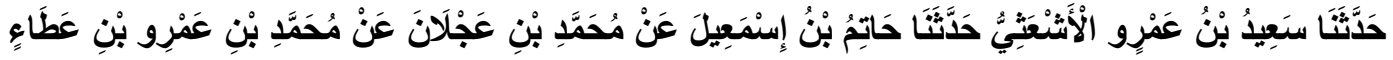

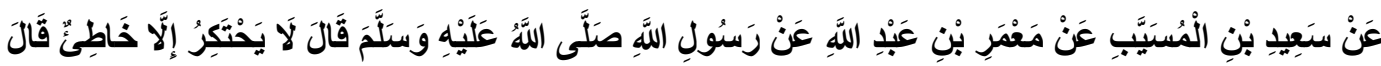

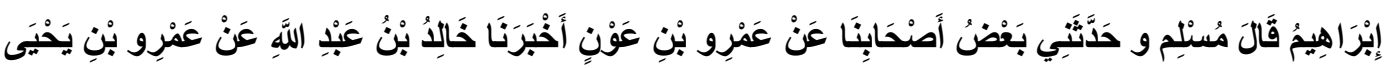

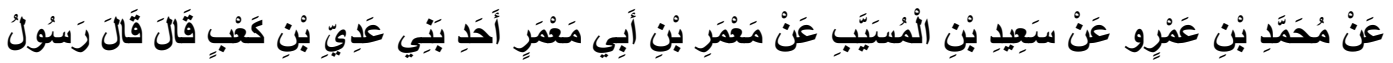

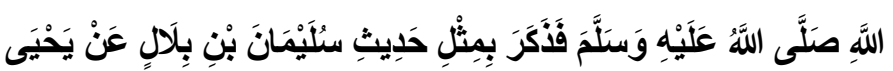

Terjemahannya:

Said bin “Amru al-Asy'atsy menyampaikan pada kami bahwa Hatim bin Ismail menyampaikan pada kami dari Muhammad bin ajlan dari Muhammad bin "Amru bin "Atha dari Said bin al-Musayyab dari Ma'mar bin "Abdullah dari rasulullah saw. bersabda: "Tidak akan menimbun kecuali orang berbuat dosa".

3. Sunan Ibn Majah

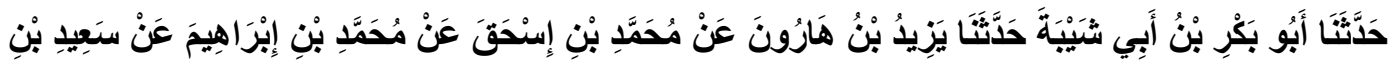

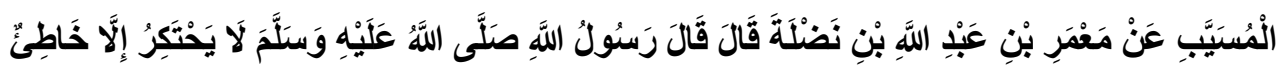

Terjemahannya:

Abu Bakar bin Syaibah menyampaikan dan Yazid bin Harun menyampaikan dari Muhammad bin Ishaq dari Muhammad bin Ibrahim dari Said bin alMusayyib dari Ma'mar bin 'Abdullah bin Nadhlah berkata bahwa Rasulullah saw telah bersabda: "Tidak akan menimbun kecuali orang berbuat dosa".

1) Kritik Sanad Hadis

Kualitas hadis mengenai hukum ihtikar, disamping ada hadis yang sudah dapat dijamin kesahihannya, ada pula yang masih diragukan dan membutuhkan penelusuran lebih jauh. Hadis Bukhari dan Muslim merupakan dua kitab hadis yang menurut banyak ulama hadis sudah tidak diragukan lagi kesahihannya terutama dalam hal ketersambungan sanadnya.

Dua hadis yang disebutkan di atas, yaitu no.1 dan 2 diriwayatkan oleh Imam Muslim. Untuk mengetahui bagaimana kualitas sanadnya masing-masing, penulis mencoba untuk menelitinya satu demi satu. Adapun aspek sanad hadis no.1, sebagai berikut:

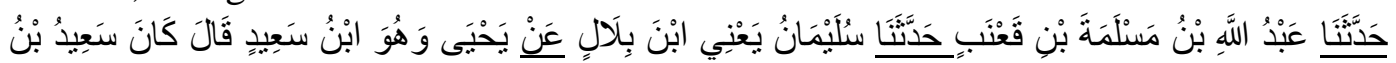
الْمُسَنَبَب يُحَدِدِثُ أَنَّ مَعْمَرًا فَّال 
Hadis pertama ini diterima oleh Imam Muslim dari 'Abdullah bin Maslamah bin qa'nabi dengan memakai lafaz حَدَّنَّا , dan 'Abdullah menerima dari Sulaiman (anaknya Bilal) dengan lafaz حَنَّنَ , lalu Sulaiman menerima dari Yahya (anaknya Said) dengan lafaz عَ, lalu dari Yahya diperoleh dari Sa'id bin al-Musayyab (ayahnya Yahya) dengan lafaz يُحََِّّ, kemudian Said menerima dari Ma'mar dengan lafaz قََّّ

Menurut Syuhudi Ismail ${ }^{3}$, kata حَنَّنَ termasuk kata yang dapat menunjukan hَ menunjukkan kedekatan antara perawi dengan perawi lainnya yang menerima hadis. Dengan demikian, periwayatan hadis dari beberapa perawi sampai kepada Imam Muslim tidak ada keraguan dari sisi ketersambungan sanadnya, sehingga menunjukkan indikator keshahihan.

Adapun hal yang berkaitan kualitas perawi baik mengenai keadilan maupun kedhabithannya, dalam kitab Shahih Muslim, telah disepakati oleh para Muhaddis dan ahli hadis atas kualitas para perawinya. Hal demikian terjadi karena sikap kehati-hatiannya dalam menerima hadis yang diterima dari perawi, sehingga apa yang diriwayatkan tidak tertolak keshahihannya, dengan demikian hadis pertama diatas bisa disebut shahih dari segi sanadnya.

Adapun hadis berikutnya juga bersumber dari hadis Imam Muslim dari kitab Shahih Muslim, dengan sanad sebagai berikut:

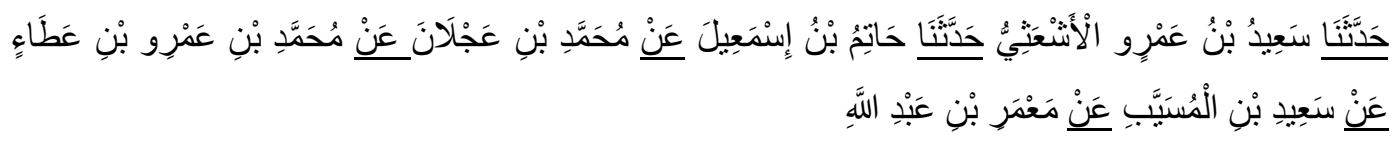

Untuk hadis kedua ini, Imam Muslim menerima dari Sa'id bin 'Amru

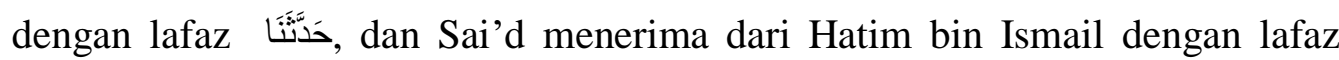
حَََّنَنا Muhamad 'Ajlan menerima dari Muhammad bin 'Amru bin 'Atha'y dengan lafaz عَ, lalu Muhammad bin 'Amru menerima dari Said bin al-Musayyab dengan lafaz عَ, dan Said menerima dari Ma'mar bin 'Abdillah dengan lafaz عَ.

Dengan memperhatikan lambang-lambang yang digunakan dalam periwayatan hadis di atas, yang menggunakan lafaz-lafaz حَنْ dan dan , dapatlah disimpulkan bahwa hadis tersebut dapat dikategorikan Shahih, terlebih lagi karena dilihat dari ketersambungan sanad telah memenuhi kriteria keshahihan hadis. Demikian pula dalam hal kualitas perawinya, karena sikap

\footnotetext{
${ }^{3}$ Syuhudi Ismail, Kaedah-Kaedah Kesahihan Sanad, (Jakarta: Bulan Bintang, 1988). h.
} 190. 
hati-hati dalam menerima hadis, maka wajarlah jika dikatakan hadis yang diriwayatkan oleh Imam Muslim tersebut di atas adalah Shahih.

Selanjutnya hadis ketiga, adalah hadis yang diriwayatkan oleh Ibn majah yang diterima melalui runtutan sanad sebagai berikut:

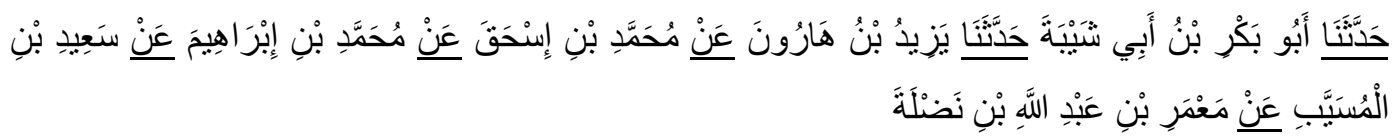

Hadis ini diterima oleh Ibn Majah dari Abu Bakar bin Abi Syaibah dengan lafaz حَدَّنَّا , kemudian Abu Bakar menerima dari Yazid bin Harun dengan lafaz

, عَنْ , dan Muhammad bin Ishaq menerima dari Muhammad bin Ibrahim dengan lafaz $َ$, dan Muhammad bin Ibrahim menerima dari Said bin al-Musayyab dengan lafaz عَ, kemudian Said menerima dari Ma'mar bin 'Abdullah bin Nadhlah dengan lafaz عَ.

Setelah menelusuri hadis tersebut dari segi lafaz / lambang yang digunakan, serta dari ketersambungan sanadnya dapatlah dikatakan bahwa hadis tersebut, sama halnya dua hadis sebelumnya, adalah shahih.

Untuk lebih meyakinkan akan keshahihan hadis dari jalur Ibn Majah , penulis mencoba untuk menelusuri dari segi kualitas perawinya. Terkait mengenai biodata, hubungan, dan keadilan serta kedhabitannya.

Periwayat I. Ma'mar bin 'Abdullah bin Nadhlah. Nama lengkapnya adalah Ma'mar bin 'Abdullah bin Nafi' bin Abi Ma'mar Nadhlah. Ia seorang sahabat keturunan Quraisy yang tinggal di Madinah, dan menerima hadis dari Rasulullah saw. Muridnya, Sa'id bin al-Musayyab bin Hazn bin Abi Wahb bin 'Amr.

Periwayat II. Sa'id bin al-Musayyab. Nama lengkapnya, Sa'id bin alMusayyab bin Hazn bin Abi Wahb bin 'Amr. Ia menetap dan wafat di Madinah pada tahun $93 \mathrm{H}$, termasuk golongan ulama tabi'in yang disegani. Di antara gurunya adalah 'Ubay bin Ka'ab, Bilal bin Rabah, Jabir bin 'Abdullah dan Ma'mar bin 'Abdullah bin Nafi' bin Abi Ma'mar Nadhlah. Muridmuridnya di antaranya, Idris bin Shahib, Hassan bin Athiyyah, Muhammad bin Ibrahim bin Haris bin Khalid.

Penilaian ulama hadis terhadapnya bisa ditemui pada Sulaiman bin Musa menilainya sebagai tabi'in yang paling berilmu (afqahu al-tabi'in). Ali bin alMadiiny berkata: "Saya tidak mengetahui orang yang lebih luas ilmunya di kalangan tabi'in selain dari Sa'id". Ahmad bin Hanbal menilainya siqah. 
Periwaat III, Muhammad bin Ibrahim. Nama lengkapnya Muhammad bin Ibrahim bin al-Haris bin Khalid. Ia menetap dan meninggal di Madinah pada tahun $120 \mathrm{H}$. Ia keturunan Quraisy. Gurunya adalah Usamah bin Za'id bin Harisah bin Syurahbil, Anas bin Malik bin al-Nadhr, Busr bin Said Maula ibn al-Hadhramy, dan Sa'id bin al-Musayyab bin Hazn bin Abi Wahb bin 'Amr. Muridnya-muridnya adalah Sa'id bin Sa'id, Imarah bin Ghaziyah bin alharis dan Muhammad bin Ishaq bin Yasir.

Penilaian ulama terhadapnya, al-Nasa'I, Yahya bin Ma'in dan Muhammad Yahya menilainya siqah.

Periwayat IV, Muhammad bin Ishaq. Nama lengkapnya Muhammad bin Ishaq bin Yasar. Ia berdomisili di Madinah dan meninggal di Baghdad pada tahun $150 \mathrm{H}$. Guru-gurunya adalah Aban bin Shalih bin 'Umair bin 'Ubaid, Ayyub bin Abi Tamimah Kaisan, Saur bin Yazid bin Ziyad, dan Muhammad bin Ibrahim bin al-Haris bin Khalid. Murid-muridnya adalah Ibrahim bin Sa'ad bin Ibrahim bin 'Abdurrahman bin 'Auf, Ahmad bin Khalid dan Yazid bin Harun.

Penilaian ulama terhadapnya, seperti Ahmad bin Hanbal menilainya sebagai hasan al-hadis. Yahya bin Ma'in, al-'Ajali menilainya siqah. Ali bin alMadini menilainya Shalih Wasath. Ibn Hibban mencantumkan namanya di dalam Kitab al-siqat, sedangkan Ibn Numair menilainya hasan al-hadis 'an alma'rufin.

Periwayat V, Yazid bin Harun. Ia berdomisili dan meninggal di Het pada tahun 206 H. Guru-gurunya adalah Ibrahim bin Sa'ad bin Ibrahim bin 'Abdurrahman bin 'Auf, Ishaq bin Yahya bin Thalhah bin 'Ubaidillah, Israil bin Yunus bin Abi ishaq dan Muhammad bin Ishaq bin Yasar. Muridmuridnya adalah Ahmad bin Sinan bin Asad bin Hibban, Ishaq bin Mansyur bin Bahram, al-Hasan bin Ali bin Muhammad dan 'Abdullah bin Muhammad bin Abi Syaiban Ibrahim bin Usman (Abu Bakar).

Penilaian ulama terhadapnya, yaitu Ibn Abi Syaibah berkata: saya tidak melihat orang yang paling baik hapalannya selain Yazid. Ahmad bi Hanbal menilainya shahih al-hadis. Yahya bin Ma'in menilainya siqah. Ali bin alMadini menilainya dengan berkata: saya tidak melihat orang yang paling baik hafalannya selainnya. Abu Hatim al-Razi menilainya siqatun imamun shadiqun la yus'alu 'an mislih.

Periwayat VI, Abu Bakar bin Abi Syaibah. Nama lengkapnya adalah 'Abdullah bin Muhammad bin Abi Syaibah Ibrahim bin Usman. Meninggal di Kufah pada tahun 235 H. Guru-gurunya adalah Abu Bakar bin 'Ilyasy bin 
Muslim, Ahmad bin 'Abdullah bin Yunus bin 'Abdullah bin Qais dan Yazid bin Harun. Muridnya adalah Imam Ibn Majah.

Periwayat VII, Imam Ibn Majah. Nama Lengkapnya Muhammad bin Yazid al-Raba'iy Abu 'Abdullah bin Majah al-Qazwiniy (209-273 H). Ia dinilai sebagai periwayat hadis yang terpuji integritas pribadi dan kemampuan intelektualnya. Hal ini bisa dilihat dari pernyataan para kritikus hadis tentang dirinya, Abu Ya'la al-Khaliliy menilainya sebagai siqah kasir, muttafaq 'alaih, pendapatnya menjadi hujjah. Dia memiliki pengetahuan luas dan penghafal hadis. Al-Zahabiy menilainya bahwa ia adalah ahli hadis dan ahli tafsir. Penyusun kitab-kitab al-Sunan, al-Tafsir, dan al-Tarikh. Ibn Kasir menilainya bahwa ia adalah penyusun kitab sunan yang termasyhur. Kitab itu merupakan bukti amal dan ilmunya yang luas. ${ }^{4}$

Tidak seorangpun yang mencela pribadi Ibn Majah. Pujian-pujian yang ditujukan kepadanya berperingkat tinggi dan tertinggi. Oleh karena itu, pernyataannya yang menyatakan bahwa ia menerima hadis tersebut dari Abu Bakar bin Abi Syaibah dengan lambang حَدَّنَا (metode al-sama'), dipercaya dan diyakini ketersambungan sanadnya.

Untuk dapat mengetahui keadaan secara umum ketiga hadis yang sedang diteliti, maka dapat dilihat pada skema yang ada di depan. Pada skema tersebut, untuk kedua jalur Imam Muslim dan satu jalur dari Ibn Majah, terlihat jelas bahwa periwayat yang berstatus syahid tidak ada karena ternyata Ma'mar bin 'Abdullah bin Nadhlah adalah satu-satunya sahabat Nabi yang meriwayatkan hadis yang sedang diteliti. Sedang untuk mutabi' ada tiga, hal tersebut bisa dilihat pada Muhammad bin 'Amr bin 'Atha', dari jalur pertama Imam Muslim maka mutabi'-nya adalah Yahya bin Said dari jalur sanad kedua Imam Muslim, serta Muhammad bin Ibrahim dari sanad Ibn Majah. Sedang untuk jalur kedua Imam Muslim maka mutabi'-nya adalah Muhammad bin 'Amr bin 'Atha' dari jalur pertama Imam Muslim, dan Muhammad bin Ibrahim. Adapun untuk jalur Ibn Majah maka mutabi'-nya adalah Muhammad bin 'Amr dari jalur pertama serta Yahya bin Said dari jalur kedua Imam Muslim.

Dapatlah disimpulkan bahwa hadis mengenai hukum ihtikar, kalau diteliti menurut sanadnya, sangat bersyarat untuk dikategorikan shahih lidzatihi. Hal tersebut tergambar dari sisi ketersambungan sanad, integritas pribadi dan kemampuan intelektual para periwayatnya.

\section{2) Kritik Matan Hadis}

${ }^{4}$ Syihab al-Din Ahmad bin 'Ali bin Hajar al-'Asqalaniy, Tahzib al-Tahzib, jilid IX (Beirut: Dar al-Fikr, 1984). h. 457.

34 
Kriteria keshahihan matan hadis menurut muhaddisin tampaknya beragam. Di antara kriteria tersebut dinyatakan maqbul (diterima) sebagai matan hadis shahih apabila memenuhi unsur-unsur sebagai berikut:

a. Tidak bertentangan dengan al-Qur'an

b. Tidak bertentangan dengan hadis yang lebih kuat

c. Tidak bertentangan dengan akal sehat.

d. Susunan pernyataannya menunjukkan ciri-ciri sabda kenabian ${ }^{5}$

Berdasar pada kriteria keshahihan hadis di atas, untuk ketiga hadis yang jadi obyek penelitian, dari segi kandungan, dapat dipastikan tidak terjadi pertentangan dengan al-Qu'an dan Hadis-Hadis lain. Meskipun dalam alQur'an tidak ditemukan teks ayat yang langsung berbicara mengenai keharaman menimbun barang dagangan, yang ada hanyalah ayat-ayat mu'amalah secara umum ${ }^{6}$ yang sebagaimana dikatakan di awal pembahasan hanyalah merupakan induksi dari nilai-nilai universal yang dikandung alQur'an. Dalam QS. al-Baqarah: 188 mengatakan:

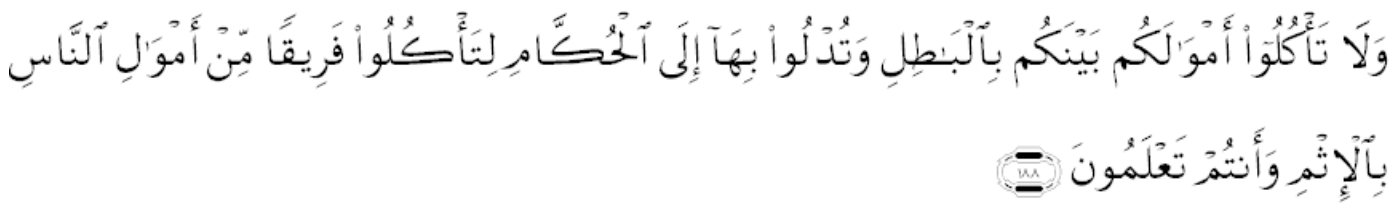

(188). Dan janganlah sebahagian kamu memakan harta sebahagian yang lain di antara kamu dengan jalan yang batil dan (janganlah) kamu membawa (urusan) harta itu kepada hakim, supaya kamu dapat memakan sebahagian daripada harta benda orang lain itu dengan (jalan berbuat) dosa, padahal kamu mengetahui.

Ayat di atas merupakan pesan utama al-Qur'an mengenai mu'amalah / aktifitas ekonomi yang menegaskan manusia untuk tidak berbuat batil dalam segala aktifitas muamalahnya, terkhusus mengenai interaksi keuangan. ${ }^{7}$ Dan pada ayat ini pula keharaman ihtikar dapat ditemukan dengan berdasar pada penafsiran lebih jauh dari ayat tersebut. Dan bertolak dari sini pula dapatlah dikatakan bahwa hadis yang jadi obyek penelitian ini tidak bertentangan dengan al-Qur'an serta hadis-hadis lain, sehingga dapat dijamin keshahihannya.

${ }^{5}$ Shalah al-Din bin Ahmad al-'Adaby, Manhaj Naqd al-Matan, (Beirut: Dar al-Afaq alJadidah, 1983). h. 238.

${ }^{6} \mathrm{Hal}$ tersebut bisa dipahami karena ayat-ayat yang berbicara mengenai masalah ibadah itu lebih kongkrit dan jelas. Berbeda ketika berbicara mengenai hal-hal yang sifatnya sosial kemasyarakatan , maka al-Qur'an menginformasikannya secara umum dan garis besarnya saja

${ }^{7}$ Quraisy Syihab, Wawasan al-Qur'an: Tafsir Maudu'l atas Perbagai Persoalan Ummat. Cet.I (Bandung: Mizan, 1996). h. 408.

35 
Sabda Rasulullah saw. yang lain dan bisa menguatkan ketiga hadis tersebut: ${ }^{8}$

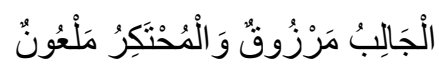

Saudagar itu diberi rezeki, sedangkan yang menimbun dilaknat. (HR. Ibn Majah).

Secara akal sehat, tindakan seseorang yang melakukan penimbunan terhadap barang-barang yang menjadi keperluan pokok orang banyak dengan tujuan untuk suatu saat akan menaikkan harganya pada saat barang-barang tersebut langka di pasaran adalah suatu perbuatan yang sangat tidak manusiawi dan tidak logis. Kalau dipikirkan secara realistis, tanpa Rasulullah mengeluarkan hadis pun perbuatan tersebut sangat tidak bisa ditolerir, terlebih lagi karena tindakan oknum yang tidak bertanggung jawab tersebut hanyalah untuk memperkaya diri sendiri hingga menyengsarakan orang banyak.

\section{B. Bentuk Pengharaman Hadis Mengenai Ihtikar}

Apa yang diungkapkan Nabi Muhammad saw. dalam ketiga matan hadis

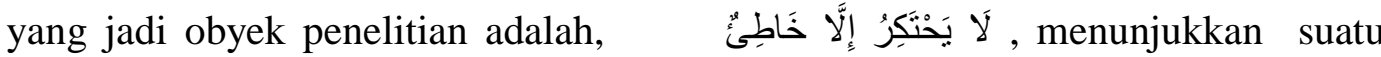
perintah kepada para pedagang untuk tidak coba-coba menimbun barang dengan tujuan agar harga naik dan baru menjualnya kepada para konsumen, sekalipun Islam memberikan kebebasan kepada setiap orang untuk menjual, membeli, dan yang menjadi keinginan hatinya. Islam menentang keras sifat egois yang mendorong sementara orang dan ketamakan pribadi untuk menumpuk kekayaan atas biaya orang lain dan memperkaya pribadi kendati harus menzalimi orang banyak. Dengan demikian hadis tersebut sangat sejalan dengan akal sehat manusia yang tidak menginginkan adanya perbuatan yang bisa merugikan orang banyak untuk kepentingan pribadi.

Adapun bukti keharaman ihtikar, dapat ditemukan dalam lafal yang berarti sebuah larangan untuk tidak melakukan sebuah perbuatan. Kata $\vee$ dalam kaedah bahasa arab bermakna خَاطِئ Munawwir diartikan dengan orang yang berbuat dosa, ${ }^{10}$ dari sini dapat dikatakan bahwa hal ini bukan kata yang biasa. Kata خَاطِئئ dalam al-Qur'an, Allah menggambarkan orang-orang yang mempunyai sifat sombong dan angkuh seperti

${ }^{8} \mathrm{CD}$. Digital hadis al-Syarif

'Zawil Badi' Ya'qub, Mausu'ah al-Nahw Wa al-Sharp Wa al-I'rab, (Cet. III: Beirut: Dar al'Ilm Li al-Malayin, 1994). h. 565.

${ }^{10}$ A.W.Munawwir, Kamus al-Munawwir Arab - Indonesia, (Yogyakarta: t.tp., 1984). h. 376.

36 
Fir'aun, Haaman, dan kelompoknya dengan ungkapan tersebut, hal ini dapat ditemukan dalam QS. al-Qashash:8.

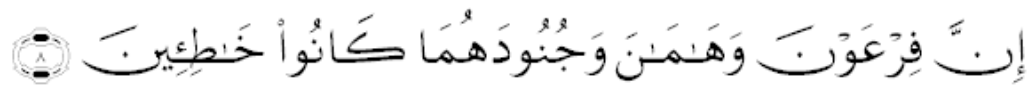

Artinya:

(8). “... Sesungguhnya Fir’aun dan Haman beserta tentaranya adalah orangorang yang bersalah."

Dari teks ayat tersebut, semakin menguatkan keyakinan mengenai keshahihan ketiga hadis di atas beserta dasar keharaman ihtikar. Sebagaimana telah diungkap pada landasan normatif bahwa tidak satupun ulama yang mengingkari keharaman ihtikar, namun yang menjadi perbedaan pendapat dalam hal ini terletak pada cara menetapkan hukum keharamannya.

Pendapat pertama dikemukakan oleh ulama syafi'iyah, Hanabilah, Malikiyah, Zaidiyah dan Zahiriyah. Menurut mereka, melakukan ihtikar hukumnya haram. Alasan yang mereka kemukakan adalah ayat dan hadis yang telah disebutkan di atas. Menurut ulama Malikiyah, ihtikar hukumnya haram dan harus dapat dicegah oleh pemerintah dengan segala cara, karena perbuatan itu memberikan mudharat yang besar terhadap kehidupan masyarakat, stabilitas ekonomi masyarakat dan Negara. Oleh karena itu, pihak penguasa harus segera turun tangan untuk mengatasinya, sesuai dengan kaidah fiqh yang menyatakan:

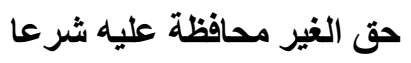

Hak orang lain terpelihara secara syara'

Dalam kasus ihtikar, yang paling utama dipelihara adalah hak konsumen, karena menyangkut hak orang banyak, sedangkan hak orang yang melakukan ihtikar hanya merupakan hak pribadi. Tatkala kepentingan pribadi bertentangan dengan kepentingan orang banyak, maka yang didahulukan adalah kepentingan orang banyak. Ulama syafi'iyah mengatakan bahwa hadis yang mengatakan bahwa ihtikar merupakan suatu pekerjaan yang salah, mengandung pengertian yang dalam. Orang yang melakukan kesalahan (al-khatha') dengan sengaja berarti telah berbuat suatu pengingkaran terhadap ajaran syara'. Mengingkari ajaran syara' merupakan perbuatan yang diharamkan. Dengan demikian, perbuatan ihtikar merupakan salah satu perbuatan yang diharamkan, apalagi dalam hadis itu pelakunya diancam dengan neraka. ${ }^{11}$

Selanjutnya, Imam al-Kasani, pakar fiqh Hanafi, berpendapat bahwa ihtikar hukumnya haram. Ia berbeda pendapat dengan pendapat mazhabnya, ia menyatakan bahwa ihtikar hukumnya haram karena banyak hadis Rasulullah saw.

${ }^{11}$ Asy-Syarbaini al-khatib, al-Mughni al-Muhtaj, Jilid II (Beirut: Dar al-Fikr, 1978). h. 38. 
yang menyatakan bahwa pelaku ihtikar dilaknat dan orang yang melakukan kesalahan dengan sengaja adalah orang yang melakukan sesuatu yang haram. Di samping itu Imam al-Kasani juga menyatakan bahwa dalam masalah ihtikar terkandung dua kemaslahatan yang bertentangan , yaitu kemaslahatan pribadi dan kemaslahatan orang banyak/konsumen. Dilihat dari tujuan syara' dengan kepentingan pribadi, maka kepentingan orang banyak yang didahulukan. Oleh sebab itu, dalam kasus ihtikar, demi memelihara kemaslahatan orang banyak, kepentingan pribadi harus dikorbankan, karena mendahulukan kepentingan pribadi dapat meresahkan orang banyak. ${ }^{12}$

Pendapat kedua dianut oleh ulama Hanafiyah ${ }^{13}$. Menurut mereka, perbuatan ihtikar hukumnya makruh tahrim (istilah hukum haram dari kalangan ushul fiqh Hanafi yang didasarkan pada dalil dzanni (relatif). Dalam persoalan ihtikar, menurut mereka, larangan secara tegas hanya muncul dari hadis yang sifatnya ahad. Sedangkan kehujjahan hadis ahad adalah zhanni. Di samping itu, sesuai dengan kaedah umum yang sifatnya qath' $i$ seseorang bebas membeli dan menjual barang dagangannya tanpa campur tangan orang lain. Menjual barang atau tidak adalah masalah pribadi seseorang. Ulama Hanafiyah tidak secara tegas menyatakan haram dalam hukum ihtikar, karena menurut mereka, dalam masalah ini terdapat dua dalil yang bertentangan, yaitu: (a) Berdasarkan hak milik yang dimiliki pedagang, mereka bebas melakukan jual-beli sesuai kehendak mereka; (b) adanya larangan berbuat mudharat terhadap orang lain dalam bentuk apapun.

Larangan di sini tidak langsung tertuju pada perbuatan ihtikar, melaingkan larangan itu muncul disebabkan mudharat yang ditimbulkan tindakan itu. Menurut mereka, mudharat ini boleh dihilangkan, karena boleh saja melakukan jual-beli yang sama sekali tidak mengandung unsur mudharat. Oleh sebab itu, menurut mereka, perbuatan ihtikar dengan alasan yang melarangnya tidak menyatu. Di samping itu, sekalipun ada hadis-hadis yang melarang ihtikar, hadis-hadis itu bersifat ahad (hadis yang disampaikan satu, dua atau tiga orang dan tidak sampai ke tingkat mutawatir), yang kekuatan hukumnya bersifat zhanni. Sesuai dengan prinsip ushul fiqh mereka, hukum haram harus ditetapkan berdasarkan dalil yang qath'i. Oeh sebab itu, mereka berpendapat bahwa ihtikar hukumnya makruh tahrim.

\footnotetext{
${ }^{12}$ Imam al-Kasani, al-Bada'i'u ash-Shana'i'u, Jilid V (Beirut: Dar al-Fikr,t.t.). h.129.

${ }^{13}$ Fathi ad-Duraini, al-Figh al-Islami al-Maqaran ma'a al-Mazahib, (Damaskus: Dar alkitab al-Hadis, 1978). h. 85-86.

38
} 
Akan tetapi, jumhur ulama dalam menetapkan hukum haram tidak membedakan antara dalil qath'i dan zhanni. Apabila ada larangan dari nas-nas (ayat atau hadis), baik sifatnya qath'i atau zhanni maka hukumnya haram. AdDuraini dalam menaggapi pandapat ulama hanafiyah ini menyatakan bahwa sekalipun hadis-hadis yang secara tegas melarang ihtikar seluruhnya ahad, akan tetapi berdasarkan istiqra' (induksi) para ulama terhadap hukum ihtikar dari berbagai ayat dan hadis, secara maknawi kekuatan dalilnya sudah qath 'i. ${ }^{14}$

Pendapat ad-Duraini tersebut sejalan dengan ungkapan al-Syafi'iy sebagaimana dikutip oleh Syuhudi Ismail $^{15}$, yang secara umum dapat disimpulkan bahwa meskipun keseluruhan hadis mengenai ihtikar adalah khabar al-khashshah (hadis ahad) namun tetap bisa dijadikan hujjah jika sanad dan periwayatan hadisnya shahih.

Dalam kasus ihtikar, pada dasarnya pemilik barang boleh menjual barangnya sesuai dengan keinginannya, tetapi akibat dari perbuatan ini orang banyak mendapat mudharat. Oleh sebab itu larangan berbuat ihtikar termasuk ke dalam kaidah di atas. Jadi pada dasarnya keharaman menimbun barang dikarenakan efek yang ditimbulkannya yang berdampak pada masyarakat secara luas.

Para ulama fiqh yang melarang tindakan ihtikar mengatakan, apabila penimbunan barang telah terjadi di pasar, pemerintah berhak memaksa pedagang untuk menjual barang itu dengan harga standar yang berlaku di pasar. Bahkan menurut mereka, barang yang ditimbun oleh para pedagang itu dijual dengan harga modalnya dan pedagang tersebut tidak berhak mengambil untung, sebagai hukuman atas tindakan mereka.

Kemudian, para ulama fiqh juga mengatakan bahwa apabila pedagang yang melakukan ihtikar enggan menjual dagangannya sesuai dengan harga pasar, maka hakim berhak menyita barang itu dan membagi-bagikannya kepada masyarakat yang sangat memerlukannya. Di samping itu, menurut mereka, pihak pemerintah seharusnya sejak semula telah mengantisipasi agar tidak terjadi ihtikar dalam setiap komoditi, manfaat dan jasa yang sangat diperlukan masyarakat.

Untuk itu, pemerintah sebaiknya melakukan penetapan harga yang adil pada setiap komoditi yang menyangkut keperluan orang banyak. Harga yang adil itu menurut jumhur ulama adalah dengan mempertimbangkan modal dan keuntungan bagi pedagang serta tidak terlalu memberatkan masyarakat. Bahkan Fath adDuraini berpendapat bahwa pemerintah tidak boleh mengekspor barang keperluan warganya sampai tidak ada lagi yang dapat dikonsumsi masyarakat, sehingga membawa mudharat bagi masyarakat. Pada hakikatnya pengeksporan barang

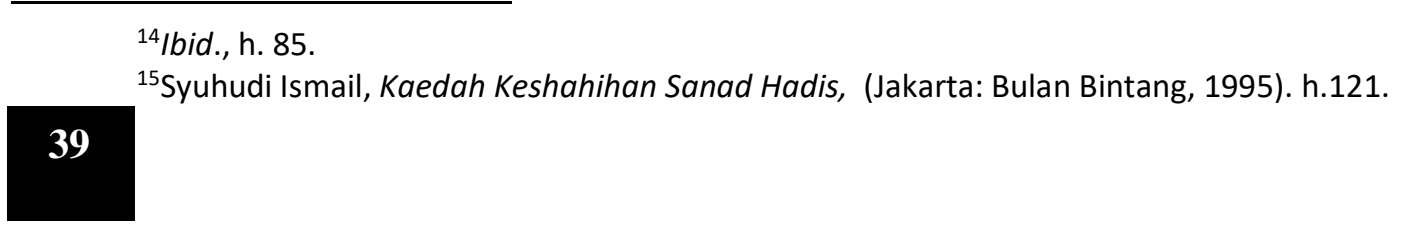


yang diperlukan masyarakat itu sama dengan ihtikar dari segi akibat yang dirasakan oleh masyarakat. ${ }^{16}$ Pernyataan Fath ad-Duraini ini didasarkan pada kaidah fiqh yang berkaitan dengan fungsi penguasa, yaitu:

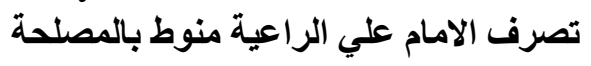

Artinya:

Tindakan penguasa harus senantiasa mengacu kepada kemaslahatan orang banyak

Oleh karena itu, menjadi suatu keniscayaan jika pemerintah harus tegas dalam menghadapi masalah seperti ini. Karena diketahui bersama bahwa pemerintah (ulul amri) idealnya menjadi pelindung dan pengayom masyarakat, dan pada saat tertentu hendaknya tegas dalam menindak mereka yang mencoba mempermainkan hukum, karena yang menjadi tujuan utama pembentukan hukum adalah demi menjaga kemaslahatan masyarakat (al-maslahah al- 'ammah) secara umum.

\section{PENUTUP}

\section{A. Kesimpulan}

Berdasarkan pembahasan diatas maka, disimpulkan sebagai berikut :

1) Berdasarkan Kaedah Keshahihan Hadis, Penelitian hadis tentang ihtikar dan terkhusus lagi pada hadis yang berkaitan dengan keharaman ihtikar yang menjadi obyek penelitian dalam makalah ini adalah berkualitas Hadis shahih, baik dilihat dari sanad maupun kualitas matannya. Oleh karena itu, hadis tersebut dapat dijadikan landasan hukum dalam penetapan hukum Islam.

2) Hadis menyatakan larangan melakukan perbuatan ihtikar dengan ungkapan "la yahtakiru illa khathi'un", mengenai hadis tersebut jumhur Ulama sepakat mengenai keharaman ihtikar. Namun demikian, mereka berbeda pendapat mengenai cara yang digunakan dalam menetapkan keharaman ihtikar. Oleh karena tindakan ihtikar dapat menimbulkan instabilitas dalam masyarakat, maka pelaku ihtikar sangat tepat bila diberi sanksi pidana yang berat dan sesuai dengan perbuatannya.

\footnotetext{
${ }^{16}$ Fathi ad-Duraini, al-Fiqh al-Islami al-Muqaran ma'a al-Mazahib, (Damaskus: Mathba'ah at-Thariyyin, 1979). h. 85-86. 


\section{DAFTAR PUSTAKA}

Al-Qur'an al-Karim

Abdul Baqi, Muhammad Fu'ad. Mu'jam li alfadzi Hadis an-Nabawiyah min Kutubu al-Tis'ah. Leiden: Brayl, 1965.

ad-Duraini, Fathi. al-Fiqh al-Islami al-Maqaran ma'a al-Mazahib. Damaskus: Dar al-kitab al-Hadis, 1978.

al-'Adaby, Shalah al-Din bin Ahmad. Manhaj Naqd al-Matan. Beirut: Dar alAfaq al-Jadidah, 1983.

al-'Asqalaniy. Syihab al-Din Ahmad bin 'Ali bin Hajar, Tahzib al-Tahzib. jilid IX, Beirut: Dar al-Fikr, 1988.

al-Gazali, Abu Hamid. Ihya' 'Ulum ad-din. Jilid II, Beirut: Dar al-Fikr,1980.

al-Kasani, Imam. al-Bada 'i'u ash-Shana 'i'u. Jilid V , Beirut: Dar al-Fikr, t.t.

al-khatib, Asy-Syarbaini. al-Mughni al-Muhtaj. Jilid II, Beirut: Dar al-Fikr, 1978.

asy-Syaukani, Muhammad Ibn Ismail. Nail al-Authar. Jilid V, Beirut: Dar alFikr, 1978.

az-Zarqani. Syarh al-Muntaqa 'ala al-Muwaththa' al-Imam Malik. Jilid V, Mesir: al-Muniriyah, t.t.

Basyir, Ahmad Azhar. Garis Besar Sistem Ekonomi Islam. Yogyakarta: BPFE, 1987.

CD.digital al-Hadis al-Syarif al-Kutub al-Tis'ah.

Departemen Agama RI, al-Qur'an dan Terjemahannya, Bandung: Risalah Press, 1989.

Dahlan, Abdul Azis. Ensiklopedi Hukum Islam. Jilid.II, Jakarta: Ichtiar Baru, 2003.

Ismail, Syuhudi. Metodologi Penelitian Hadis Nabi. Jakarta : Bulan Bintang, 1992.

Ismail, Syuhudi. Kaedah-Kaedah Kesahihan Sanad. Jakarta: Bulan Bintang, 1988.

Qardhawi, Yusuf. Halam dan Haram dalam Islam. Surabaya: Bina Ilmu, 2003.

Rizvi, Sayyid Muhammad. Kecendrungan Rasionalisasi dalam Hukum Syari'at, Jurnal al-Huda,Volume Nomor 2002.

Syihab, Quraisy. Wawasan al-Qur'an: Tafsir Maudu'I atas Perbagai Persoalan Ummat. Cet.I, Bandung: Mizan, 1996.

Ya'qub, Zawil Badi'. Mausu'ah al-Nahw Wa al-Sharp Wa al-I'rab. Cet. III: Beirut: Dar al-'Ilm Li al-Malayin, 1994. 